\title{
Fekete pedagógia, avagy hallgatói tapasztalatok az informatika tantárgy oktatásáról
}

\author{
Lénárd András \\ Eötvös Loránd Tudományegyetem TÓK Digitális Pedagógiai Tanszék
}

\begin{abstract}
Absztrakt
A szerző a fekete pedagógia jelenségköréből és a pedagógus kutatások eredményeiből kiindulva vizsgálja, hogy tanító szakos pedagógushallgatók milyen tapasztalatokkal rendelkeznek, a közoktatás keretein belül megvalósuló informatika oktatásukról. A tanulmány bemutatja, hogy a pedagógushallgatók tapasztalai, vélekedései hogyan hatnak az informatika tantárgy témaköreinek, azok tartalmának és vélt hasznosságának megítélésében. Részletes elemzésre kerül, mely területeket és tartalmakat erösítenének, illetve hagynának el, valamint milyen személyes, negatív tapasztalatokkal, élményekkel rendelkeznek pedagógushallgatók a tantárggyal kapcsolatban. A nem reprezentatív vizsgálat tapasztalatai jól hasznosíthatóak az informatika tantárgy tartalmi és módszertani megújítása során, az újonnan létrehozott digitális kultúra tantárgy tantervi tartalmainak kialakításánál. A vizsgálatból levont tapasztalatok összhangban voltak a tantervfejlesztök azon törekvéseivel, hogy az információs társadalom elvárásainak és a tanulók érdeklődésének, életkori sajátosságainak megfelelő tantárgy születhessen. A kutatás tapasztalatai jól hasznosíthatóak a tanítóképzésben is, a fekete pedagógia hatásrendszerének kiküszöbölése, valamint a korszerü módszertani megoldások kialakítása révén.
\end{abstract}

Kulcsszavak: informatika, fekete pedagógia, tapasztalatok, tantervfejlesztés, emlékezés

\section{Az informatika tanításának téveszméi}

Az informatikaoktatásban tapasztalható sikertelenségek és téveszmék kutatása nem újkeletü. Az egyik legismertebb hazai munka Szlávi Péter és Zsakó László $A z$ informatikaoktatás téveszméi címü tanulmánya (Szlávi \& Zsakó, 2003). Sajnálatos módon, az írásban több mint 15 éve megemlített téveszmék, súlypont-eltolódások, hibás gyakorlatok napjainkban is jellemzőek. A teljesség igénye nélkül az informatikaoktatás hőskorában a következő problémák körvonalazódtak:

Sokan az informatikát kizárólag alkalmazói ismeretek gyűjtőhelyének tekintették. Az oktatás egy-egy szoftver és néhány funkció megtanítására 
korlátozódott. Az egyes ismeretkörök nem tartalmaztak azonos kapcsolódási pontokat, és főleg nem álltak kapcsolatban a napi gyakorlattal. Egymás után következő, azonos súlyú ismeretkörönként tanították az alkalmazandó új ismereteket. Rengeteg gyermek számára elvont, a gyakorlattal semmilyen kapcsolatban nem álló tudáselem került az informatika ismeretanyagába. Az elméleti anyagrész a gyerekek számára sokszor megfoghatatlannak és feleslegesnek tünt, így például a számítógép felépítése vagy akár a bináris aritmetika. A kutatásban gyakran említésre került a pusztán elméleti ismeretek számonkérése a gyakorlattól és a közvetlen hasznosulástól függetlenül.

Sajnos a közelmúltban végzett kutatásomban is körvonalazódott, hogy a 2003-ban megfogalmazott téveszmék 2019-ben is jelen vannak. Ez különösen a pedagógusképzés területén jelent veszélyt, hiszen ezek a téveszmék az informatikát tanító pedagógus téveszméiként, hatványozottan vannak jelen, és nagyon sok tanulót érintve élnek tovább, illetve terjednek.

A pedagóguskutatások (Falus, Golnhofer, Kotschy, M. Nádasi, \& Szokolszky, Á., 1989) megmutatták, hogy a tanítás során rendkívül erőteljesen hatnak a pedagógusok előfeltevései, prekoncepciói és előítéletei. A prekoncepciók érzelmektől átitatottak és gyakran a közvetlen valóságból táplálkoznak (Wubbels, 1992). Az is ismert jelenség, hogy amennyiben a prekoncepció ellentétbe kerül a tanult tudáselemekkel, példákkal, a pedagógus döntéseiben, cselekvéseiben gyakran a prekoncepció hat erőteljesebben (Pajares, 1992). A pedagógusok tevékenységeiben, alkalmazott didaktikai és módszertani megoldásaiban a szaktudományos ismeretek, illetve a pedagógusképzésben tanultak ellenében sokszor a saját, tanulóként megélt, az oktatási gyakorlatban tapasztalt momentumok hatnak. Ez a hatás még abban az esetben is kifejezett, ha azokat a pedagógus nem kellemes élményekként vagy nem hasznos komponensekként élte meg. A pedagógusképzésben tapasztaljuk az iskolai gyakorlatok során, hogy egy-egy helytelen pedagógiai megoldás indoklásaként gyakran említik a hallgatók azt az érvet, miszerint ezt a gyakorlatot velük szemben is alkalmazták diákkorukban. Nagyon sokszor akkor is megismétlik ezeket a helytelen lépéseket, ha ezek a lépések számukra is kedvezőtlenek voltak. A „velem is ezt csinálták” érv gyakran felmerül hallgatók pedagógiai tevékenységeinek elemzése során is.

\section{A fekete pedagógia hatásrendszere}

Kutatásomban az informatikatanítás területén szerzett olyan közvetlen tapasztalatokat vizsgáltam, melyek hatással lehetnek a pedagógusjelöltek későbbi tanítási tevékenységeire. Az informatika módszertan tantárgyban kooperatív technikákat alkalmazva nagyon gyakran kerültek felszínre olyan rossz gyakorlatok, módszertani és szakmai hibákat sem nélkülöző, diákként tapasztalt tevékenységek, melyek továbbélése, esetleges megismétlése rendkívül káros lehet.

A tanulókat ért kedvezőtlen, leginkább az értékelésben megnyilvánuló hatásokról fekete pedagógia néven először 1988-ban, (Rutschky, 1988), majd 
egy hazai kutatás kapcsán 2006-ban olvashattunk (Hunyadyné, M. Nádasi \& Serfőző, 2006). A kutatók a fekete pedagógia gyűjtőfogalom alá sorolták mindazon negatív hatásokat, amelyek az iskolai évek alatt oly módon érték a tanulókat, hogy azok hatásai még évek múltán, sokszor évtizedes távlatokban is jelentkeztek. Ezeket a hatásokat rendkívül nehezen lehet kimutatni és mérni, valamint hatásrendszerük is csupán becsülhető.

„Hogy a pedagógiát akadémiai szinten müvelök nem szivesen tévednek az itt jelzett, meglehetösen ingoványos területre, azon nem lehet csodálkozni. Hiszen olyan komplex, gyakran inkább érzelmi úton megközelithetö, korlátozottan mérhetö problémakörröl van szó, amelynek csak a felszine érzékelhetö közvetlenül, a mélyben kavargó, rendkívül komplex, diffúz és rengeteg szubjektív elemet tartalmazó világa inkább csak sejthetö, mint részleteiben megismerhetö és biztonsággal megfejthetö." (Szekszárdi, 2007)

\section{A fekete informatika meghatározása és kiküszöbölésére tett erőfeszítések az oktatásszabályozó dokumentumokban}

Ezek a kedvezőtlen hatások az informatika tanulása során is jelentkeznek. Míg Hunyadyné, M. Nádasi és Serfőző elsősorban az értékelésben megnyilvánuló kedvezőtlen hatásokat térképezték fel (Hunyadyné et al., 2006), kutatásomban ezen felül a tananyaggal és a tananyag elsajátításával kapcsolatos módszertani háttérre vonatkozó negatív hatásokat is vizsgálom. A címben szereplő fekete informatika kifejezés, melyet kizárólag ennek a vizsgálatnak a céljára alkalmazok, kicsit szűkebb és más értelmü, mint a mára Rutschky (1988), valamint Hunyadyné és munkatársai nyomán meghonosodott fekete pedagógia kifejezés. Fekete informatika alatt mindazokat a kedvezőtlen pedagógiai hatásokat értem, melyek alkalmasak az informatika tantárgy iránti negatív attitűd kialakítására, a téveszmék és a helytelen pedagógiai gyakorlatok stabilizálására.

A fekete informatika összetevőinek feltárására több okból is szükség volt. Egyrészt az ELTE Tanító- és Óvóképző Kar informatika módszertan tantárgyának keretében fel kell készítenünk a hallgatókat az alsó tagozatban az informatika, illetve a 2020-as Nemzeti alaptanterv hatálybalépése után a harmadik osztálytól bevezetendő, részben informatikai természetű digitális kultúra tantárgy tanítására. Másrészről, a felsőoktatásnak kiemelt felelőssége van a napi pedagógiai tevékenységekre gyakorolt hatása révén. Nemcsak a pedagógusjelöltek képzésében, hanem a gyakorló pedagógusok továbbképzése során, szakmai konferenciákon, workshopokon nyílik lehetőség a kedvezőtlen hatások, lehetőségek, alternatívák, módszertani megoldások bemutatására, melyek oldhatják ezen tendenciákat, ezáltal, a fekete informatikával kapcsolatos kutatások a pedagógus továbbképzések anyagává is válhatnak. A harmadik terület, melyben a legkifejezettebben felhasználásra került a fekete informatikával kapcsolatos kutatás, az új Nemzeti alaptanterv 
megalkotása volt. Az informatika tantárgy újragondolása alkalmával szembesültünk azokkal a rossz beidegződésekkel, negatív tendenciákkal, melyek gyengítették az informatika tantárgy pozícióját.

A tartalmi megújítás számos olyan pontot tartalmazott, mely szakított az eddigi informatika tanítási gyakorlattal, mondhatjuk informatikai tabukat döntött le. Mindenképpen szerettük volna valahogyan jelezni a pedagógusok, tanulók, szülők és általában az egész társadalom felé azt, hogy a tanterv fejlesztése során gyökeres irányváltásban gondolkodtunk. Igyekezetünk szerint részben lebontottuk a fekete informatika hatásrendszerének elemeit, új területeket, tudáselemeket emeltünk be, melyeket mindenképpen hasznosnak gondoltunk a digitális környezetben történő problémamegoldás tanításának folyamatában. Mivel a változások meglehetősen mélyrehatók voltak, új területek jelentek meg, melyek minden bizonnyal módszertani megújulást is hoznak majd.

A tantárgy nevének megváltoztatásával, az új tartalmak névbeni kifejezésre juttatásával is szerettük volna jelezni az informatika mint tantárgy megújításának szándékát. Ez a szándék az informatikát tanító pedagógusok egy részénél erős ellenérzéseket szült. Az évtizedes gyakorlat megváltoztatására irányuló törekvésekkel kapcsolatos ellenállás ismert jelenség a pedagógia történetében. Itt azonban, támaszkodva a szakirodalmi háttérre is, megállapíthatjuk, nem kizárólag kényelmi, illetve beidegződésbeli szempontok domináltak. Tapasztalhattuk, hogy azok a téveszmék, melyekre Szlávi és Zsakó (2003) rámutatott, illetve, melyek ebben a kutatásban is felszínre kerültek, valóban élő, létező és hiedelmekkel, laikus elképzelésekkel, valamint félreértelmezett tapasztalatokkal körbebástyázott eszmerendszert alkotnak.

\section{Az informatika tanulása során szerzett tapasztalatok vizsgálata}

A vizsgálatban azt szerettem volna feltárni, hogy milyen negatív, informatikatanulással kapcsolatos emlékek hatnak a pedagógushallgatók informatika oktatással kapcsolatos vélekedéseire. Természetesen, ezeket az emléknyomokat a felidéző érzelmi hátterével, laikus és professzionális pedagógiai nézeteivel megfeleltetve ismerhetjük meg a vizsgálat során. Az informatika tantárgy tanításának folyamatában felmerülő problémákat jól jelzik a PISAtesztek digitális kompetenciával kapcsolatos méréseinek eredményei. Ezek kijózanító módon leszámolnak azzal a mítosszal, miszerint a felnövekvő generációk (digitális bennszülöttek, Z-generáció...) igen fejlett digitális kompetenciákkal rendelkeznek, eszközhasználatuk kiváló, s e tudás megszerzéséhez nincs szükség külön tantárgyra, hiszen ők beleszülettek a digitális korba. Ezzel szemben a vizsgálat kimutatta, hogy a magyar, jelenleg 16 éves korosztály nagy többsége gyakorlatilag digitális analfabétának tekinthető (Az Iskolai Digitális Oktatás Megújítási Terve, 2016). Ez a kifejezés nem a digitális eszközök kezelésének hiányosságaira utal, hiszen ebben, bizonyos alkalmazások esetén (melyek leginkább a közösségi médiára vonatkoznak), kifejezett rutin figyelhető meg. 
A digitális írástudatlanság a digitális környezetben, digitális eszközökkel történő problémamegoldás hiányosságait jelenti. Leginkább azt, hogy a vizsgált korosztály nem képes hatékony módon az információs társadalomban felmerülő problémák megoldása során a rendelkezésre álló digitális eszközöket alkalmazni.

A kutatást az ELTE TÓK-on 2018-ban, illetve 2019-ben másod- és harmadéves tanító szakos pedagógus jelöltek körében végeztük $(\mathrm{N}=189)$. A kutatás írásbeli kikérdezéssel valósult meg, részben Likert-skála, részben nyílt végü kérdések, illetve feleletválasztás segítségével. A kérdőíveket webes felületen töltötték ki a hallgatók, több csoportban, a csoportokban azonos időpontokban, géptermi környezetben. Ezáltal viszonylag nagy mennyiségü választ kaptunk egy jól körvonalazható körből. A szervezett keretekkel sikerült kiküszöbölni a webkérdőívek alkalmazásának azon hátrányát, miszerint a kitöltők köre nagyon nehezen kontrollálható.

A kérdések összeállításánál a jelenleg használt informatika tananyag egyes összetevőinek vélt hasznosságára, a tanulás problémáira, és az informatikaórák tartalmára, időbeosztására, a pedagógusok reakcióira voltunk kíváncsiak. Jelen tanulmány a kutatás fontosabb eredményeit emeli ki.

A vizsgált korosztály általános-, illetve középiskolai éveinek idején a 2012es Nemzeti alaptanterv, illetve annak elődje volt hatályos. Ezekben a tantervekben az egyes témakörök hasonlóak voltak. Éppen ezért elmondhatjuk, hogy viszonylag kevés tartalmi változás következett be abban az időszakban, amikor a vizsgálat mintájába került pedagógus hallgatók informatikát tanultak. Természetesen tisztában vagyunk azzal, hogy a visszaemlékezés föleg az alsó tagozatos informatikatanítással kapcsolatos tapasztalatokra nem könnyű, és számos torzulással járhat. Ez azonban természetes velejárója a negatív tapasztalatok kutatásának, ugyanis ezek a tapasztalatok legtöbbször mélyen rögzülnek, és sokáig, összetett hatásrendszerben hatnak.

A vizsgálat természetesen nem reprezentatív, a teljes, azonos életkorú, informatikát tanult populációra nem vonatkoztatható. A cél nem is elsősorban egy teljes generációra vonatkozó tapasztalatok összegyüjtése volt, hanem leginkább az, hogy bizonyos csomópontokat, a mintán belüli ismétlődéseket fedezzük föl. Az eredmények alapján feltételezzük, hogy ezek a tendenciák több, azonos életkorú személynél is hatnak, ez azonban jelen kutatás alapján egyértelmủ bizonyítást nem nyerhet. A minta abból a szempontból sem reprezentatív, hogy a tanítóképzésre jelentkező hallgatókat nem elsősorban az informatikai természetű érdeklődés jellemzi. A minta mintegy 20 fős része ugyan informatika műveltségterületi képzést kap, ám az ő válaszaik sem különböznek egyértelműen az egyéb műveltségterületen tanuló hallgatók válaszaitól. Bár a minta hallgatói a legtöbb esetben nem részesültek erőteljes informatikai képzésben, mégis nagyon fontosak tapasztalataik abból a szempontból, hogy mindannyian jogosultak lesznek az informatika tantárgyi tartalmainak, 2022-től a digitális kultúra tantárgy tanítására az alsó tagozatban, a műveltségterületi képzést kapott hallgatók pedig a 6. osztályig. 
Azzal is tisztában vagyunk, hogy a vizsgálat rengeteg szubjektív szempontot tartalmaz, ezért a tantárgy tanulásával kapcsolatos esetleges sikertelenségek, nehézségek a vizsgáltakon túl, más okokra is visszavezethetőek. Természetes azonban, hogy az érdeklődésbeli, a személyiségjegyekkel öszszefüggő, a technikai feltételekről szóló szempontok ugyanúgy dominálnak, mint a tárgyat tanító pedagógus kompetenciáinak minősége, alkalmazott módszertani megoldásai.

Elsőként arra voltunk kíváncsiak, hogy a teljes eddigi életük során átélt informatika tanítási folyamatot mennyiben élték meg sikeresként. A kérdés arra vonatkozott, mennyire tartotta hasznosnak a teljes tanulói státuszban átélt informatikatanulást az adott hallgató. A 10-fokú Likert-skálán elhelyezkedő válaszok alapján inkább sikeresnek, illetve hasznosnak tartották a folyamatot. A legtöbb válasz az 5-ös és a 8-as érték közé esett. Viszonylag alacsony volt azoknak a válaszoknak a száma, melyek teljesen haszontalannak, vagy éppen igen hasznosnak ítélték a folyamatot. Nyilvánvaló a válaszadásnál dominálhatott a skála közepére való pozicionálás, mely a kedvező és a kedvezőtlen hatások egyensúlyára utal.

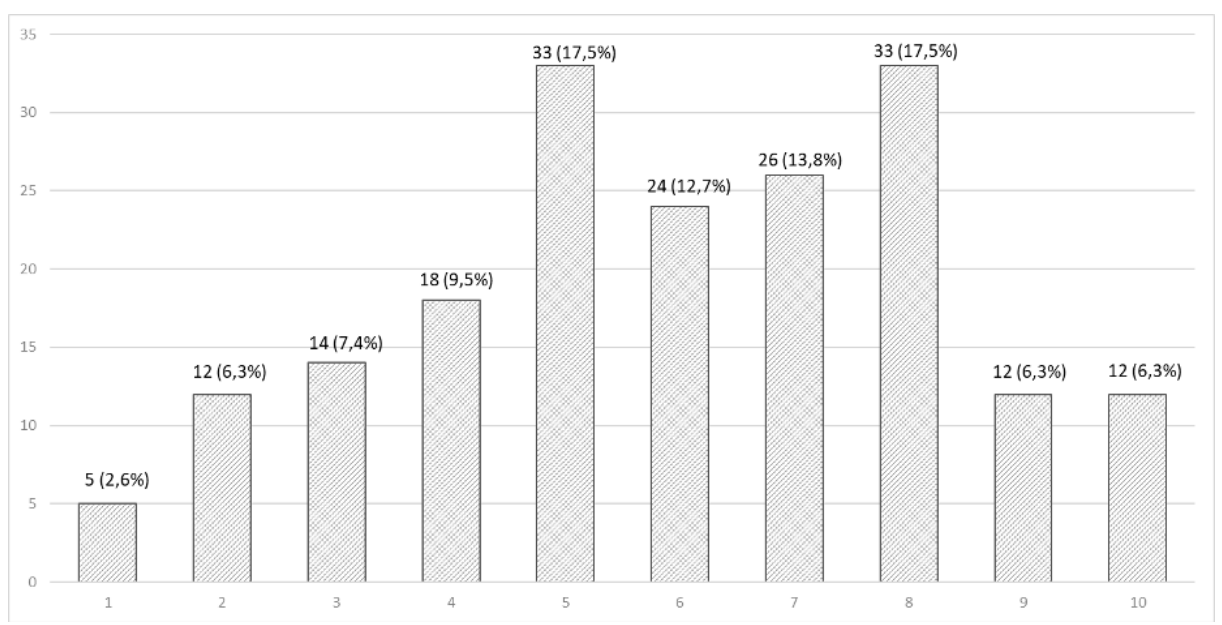

1. ábra

A teljes, közoktatásban eltöltött idö alatt mennyire tartották sikeresnek egy 1-10-es skálán pedagógushallgatók az informatika tanulásának folyamatát. $(N=189)$

Tisztában vagyunk azzal, hogy az adott válaszok a hallgató által vélt (és nem feltétlenül valós) hasznosságra, sikerességre vonatkoznak. Ezt befolyásolhatja nemcsak a megszerzett tudás mélysége, az átélt tanítási szituációk hangulata, hanem az is, hogy az adott hallgató további élete során milyen gyakran és milyen sikerrel alkalmazta a megszerzett tudást. Természetesen 
itt is lényeges szempont a minta nem reprezentatív volta, ezáltal tehát a teljes populáció informatikatanításának hasznosságáról nem vonhatunk le következtetéseket.

Természetesen az időbeni torzulás jelenségével számolva megkérdeztük a hallgatókat, hogy általános-, illetve középiskolában, becsléseink szerint az informatika órák mekkora részét töltötték céltalan, úgynevezett „szabadfoglalkozással”. Az eredmények alapján látható, hogy eléggé domináns tevékenységforma volt a tanítás nélkül, szabadfoglalkozással eltöltött informatikai tevékenység. Már a hallgatókkal történő, informatikaoktatási tapasztalataikkal kapcsolatos beszélgetések során is igen gyakran felmerült, hogy az informatikaórák jelentős része ezzel az ellenőrizetlen tevékenységgel telt. A válaszadók visszaemlékezései alapján a minta 7,9\%-ánál szinte minden esetben, 38\%-ánál pedig gyakran teltek az informatikaórák „szabadfoglalkozással", vagyis feladat, szempont nélküli szabadon végzett számítógépes aktivitással, mely a leggyakrabban játék, illetve szabadon választott témájú böngészés volt. A válaszadók mindössze 7,6\%-a nem találkozott szinte sosem ezzel a tevékenységgel az informatika tanulása során. Visszaemlékezéseik során a hallgatók ezt az ellenőrizetlen, szabad tevékenységet, játékot igen-igen kedvezőnek ítélték meg, és kedvelt tevékenységként emlékeztek rá. A válaszadók 46,3 \%-a legkedveltebb tevékenységként jelölte.

A saját tapasztalatok szerepét ismerve megkérdeztük a válaszadóktól, hogy ők maguk mennyire engedélyeznék a hallgatóknak a mindenfajta megkötés, feladatadás, szempont nélküli informatikai eszközhasználatot az informatikaórán. Az eredmények tükrében elmondható, hogy a minta esetében nem érvényesül a saját, kedvezőtlen tapasztalatok dominanciája a későbbi pedagógiai tevékenységnél, mert a hallgatók szinte soha nem élnének ezzel a lehetőséggel. 53\%-uk csak nagyon ritkán, míg 23\%-uk sosem engedélyezné informatikaóra keretében a tejes „szabadfoglalkozást”. Nagyon lényeges, hogy ezt a tevékenységet a kérdőívben egyértelmüen megkülönböztettük az adott cél érdekében folytatott szabad alkotó tevékenységtől! Tisztában vagyunk azzal, hogy ez még csak a majdan bekövetkező tevékenységről alkotott vélekedés, és a napi gyakorlat, többek között az eszközök hiánya, azok müködésképtelensége, a megfelelő pedagógus kompetenciák hiánya, a kiégés stb. nagyon gyakran hatnak abba az irányba, hogy mégiscsak engedélyezésre kerül az óra alatti teljesen ellenőrizetlen és céltalan tevékenység. A hallgatók válaszaiban közrejátszhatott az is, hogy amikor ők általános iskolások, középiskolások voltak, igen érdekesnek tűnt ez a tevékenység, hiszen otthon a legtöbb háztartásban még nem álltak rendelkezésre ezek az eszközök. Nyilván későbbi életük során a hallgatók nagy többségükben szinte akkor kerülnek kapcsolatba informatikai eszközökkel, amikor csak szeretnének, internet-hozzáférés nem csak az iskolában van, hanem a mindennapok természetes velejárójaként mindenhol, ezért már messze nem annyira csábító ez a tevékenység, mint volt megközelítőleg tíz évvel ezelőtt.

A jelenlegi Nemzeti alaptantervben, illetve a digitális oktatás keretei között egyre gyakoribb tevékenység a más tantárgyak területén történő digitális alkal- 
mazások, tananyagok használata. A válaszadók ezt a tevékenységet is döntően kedveltként jelölték meg, a válaszok kimagaslóan nagy része tevődött az 5-től 10-ig terjedő skála területére. Ez abból a szempontból örvendetes, hogy a jelen oktatási szituációban - gondolok itt a 2020. március 16-ától bevezetett digitális oktatás időszakára -, ezek az alkalmazások, digitális tananyagok ugrásszerúen felértékelődtek, és a digitális oktatás zömét adják. Nyilvánvaló, ha a pedagógusjelöltek ennek a területnek még a digitális oktatás bevezetése, vagy akár felmerülése előtti időszakban ilyen jelentőséget tulajdonítottak saját gyakorlatukban is, várhatóan erőteljesen hatnak majd ezek a tananyagok a későbbiekben is.

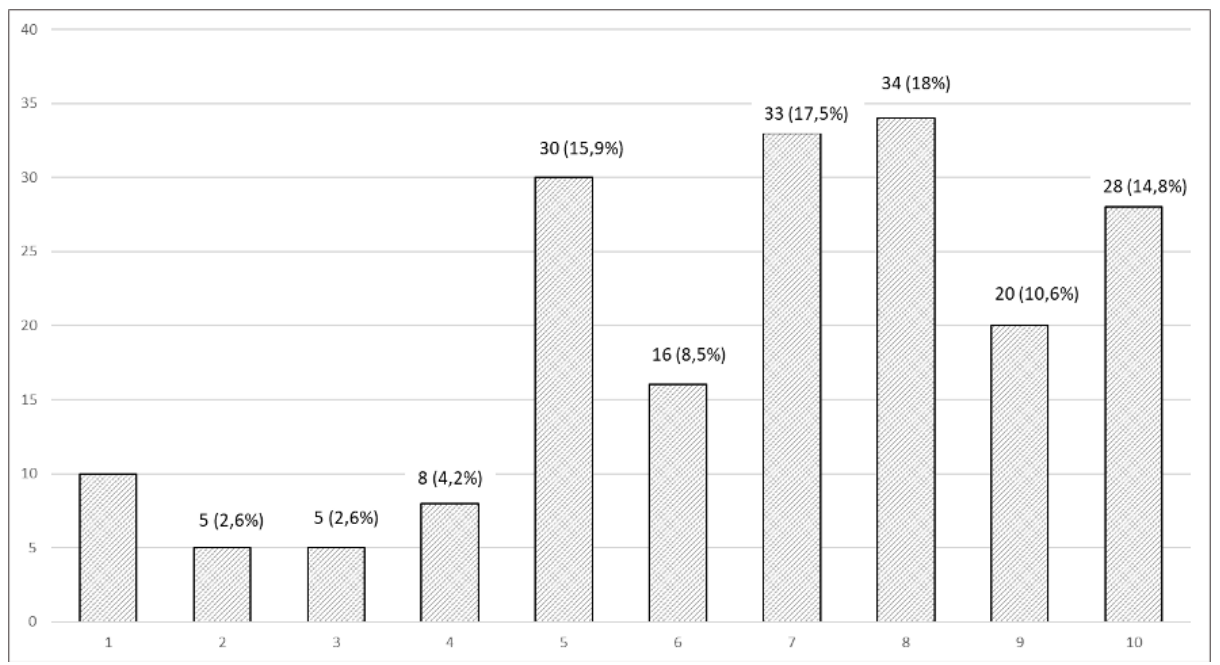

2. ábra

Mennyire tartották fontosnak egy 1-10-es skálán pedagógushallgatók a digitális tananyagok, alkalmazások használatának megtanulását az informatika tantárgy keretein belül. $(N=189)$

A 2012-es, és főként az azt megelőző, Nemzeti alaptanterv informatika tananyagának sajátos területét adták a számítógép, illetve annak hardver környezetével kapcsolatos tudáselemek. Az itt tanítottak gyakran nem álltak összhangban a gyerekek érdeklődésével, meglévő tudásával, éppen ezért ez nagyon sokszor jól számonkérhető, de a gyerekek számára teljességgel indifferens tananyagrész volt. Ez a hallgatók válaszaiból is kitünik, ugyanis igen erőteljesen, 31,5 \%-ban tartották teljesen szükségtelennek ezt a tananyagrészt, így az adott válaszok döntő többsége az 1 és 5 skála értéke közötti területre tevődik. Többek között ennek a vizsgálatnak is köszönhetően az új Nemzeti alaptantervben, alsó tagozatban ez az anyagrész teljesen hiányzik, és felső tagozatban sincs jelen önálló elméleti tananyagként. 
Érdekes azonban a programozás hasznosságáról való vélekedés ennél a korosztálynál. A programozás számukra leginkább a Logo programozási környezetet, azon belül is a Comenius Logo alkalmazást jelentette. A válaszokból kitűnik, hogy két jól kivehető csoport különül el a mintában. Az egyik, a legerőteljesebb réteg 33,9\%-ban teljesen haszontalan dolognak ítélte meg a programozást, míg egy másik kifejezett réteg a skála közepére, az 5-ös értékre tette ennek hasznosságát. Szinte elenyésző azon válaszadók száma, mindössze $1,1 \%$, akik kifejezetten hasznosnak ítélték meg a programozást.

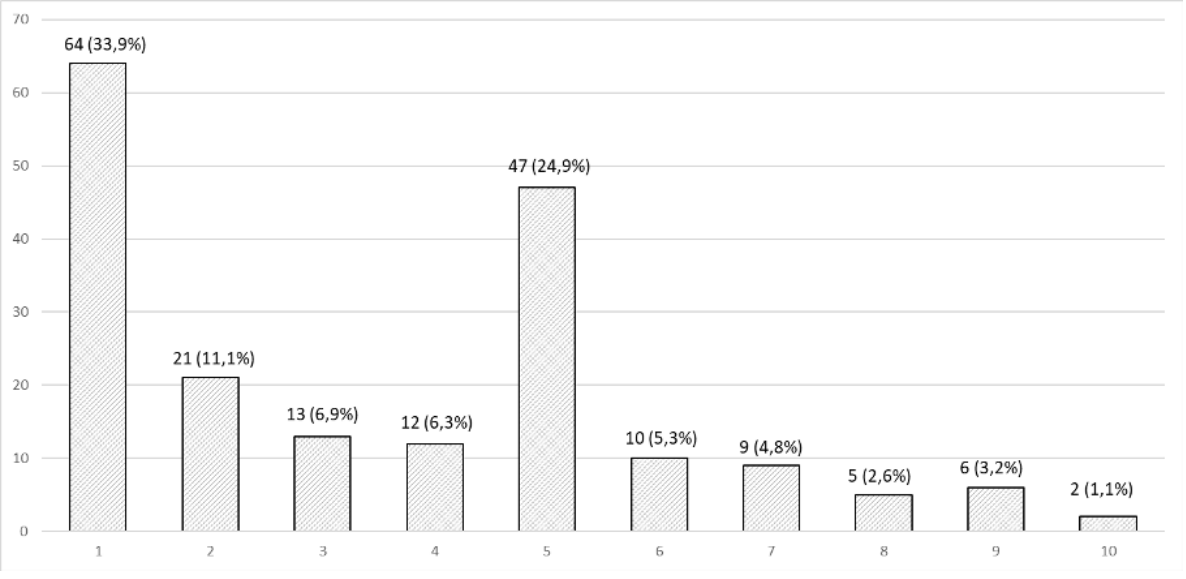

3. ábra

Mennyire tartották fontosnak egy 1-10-es skálán pedagógushallgatók a programozás tanulását az informatika tantárgy keretein belül. $(N=189)$

Ebből logikusan az következne, hogy ez az anyagrész is jelenjen meg csökkenő jelentőséggel az új Nemzeti alaptantervben. A további válaszok azonban árnyalják a témakör tanulói megítélését. A programozás, illetve a kódolás és az azzal szoros kapcsolatban lévő robotika témakör mára igen kedvelt, a gyerekek számára igen élvezetes módon tanítható tudásterületté fejlődött. (6. ábra) A probléma forrása nem magában a programozásban, hanem a programozási környezetben, történetesen a Comenius Logo-ban keresendő. Egy másik helyen a legkedvezőtlenebb informatikai tapasztalatok terén is vezető pozícióban szereplő Comenius Logo, (5. ábra) bár kétségkívül fejleszti az algoritmikus gondolkodást, nem veszi figyelembe a most felnövekvő gyermekek életkori sajátosságait. A program kezelőfelülete nehézkes, grafikai megvalósítása rendkívül absztrakt gondolkodást feltételez a programozási tevékenység megvalósítása során. A kapott feladatok legtöbbször semmilyen kapcsolatban nincsenek a valósággal, és a gyerekek semmilyen példát nem láthatnak az őket körülvevő környezetben arra, hogy a Comenius 
Logo-ban megtanult programozási eljárásokat valahol is hasznosítani tudják. Kétségtelen, hogy a programozási környezet gondolkodásra gyakorolt hatása kedvező, azonban ennek használatát a kellő motivációs bázis hiánya miatt a tanulók eredményeink alapján nem tartják fontosnak. A tanulság ebből számunkra nem az volt, hogy száműzni kell ezt a témakört, hanem az, hogy közelíteni kell az életkori sajátosságokhoz, azaz tevékenységcentrikusan, motiváló környezetben, és leginkább alkotó módon, az egyéni elképzelések, sajátosságok figyelembevételével, a kreatív megoldások kibontakoztatásával szükséges tanítani. A vizsgálat rendkívül sok hasznos háttérinformációval szolgált a tananyagfejlesztő tevékenységhez.

A másik kiemelt terület az informatika tanításában a grafikus alkalmazások használatának megalapozása. Ennek vélt hasznosságával kapcsolatban itt is jól kivehető hallgatói csoportok körvonalazódnak. Az adatok egy része, mintegy $10 \%$-a teljességgel haszontalannak tartja ezt a területet, zömük átlagosan fontosnak, és mintegy $50 \%$-uk a 6-os és 10-es skála értékek köré pozícionálja a grafikus alkalmazások tanulásának fontosságát. A tapasztalatokról folytatott, részben kötetlen beszélgetések alapján a teljességgel haszontalannak ítélők táborának múltjában minden bizonnyal a Paint alkalmazás hoszszú időn át történő, és az unalomig fokozódó gyakorlása állhat. Igen gyakori ugyanis, hogy ezt az amúgy nem gyermekek számára készült alkalmazást, melynek lehetőségei meglehetősen szükek, sokszor féléveken keresztül gyakorolják a gyerekek újabb és újabb alkotásokat hozva létre. Ez a munka a gyerekek egy részének nem szabad alkotásnak, hanem tevékenységük erőteljes behatárolásának, digitális írástudásuk adott szinten való konzerválásának tekinthető. A támogató tábor leginkább a jelen környezet kihívásaiból táplálkozhat, hiszen későbbi tevékenységük, munkájuk során a hallgatók nagyon gyakran érezhették szükségét számítógépes grafikai megoldások létrehozásának, illetve különböző produktumokban való megjelenítésének.

A másik terület az adatbázis-kezelés, melyet a válaszadók döntő többsége az 1-es és 5-ös értékek közé helyezett. A válaszok hátterében nyilvánvalóan az áll, hogy egy általános iskolás, de egy középiskolás tanuló életében is az eddigi időszakban nagyon ritka volt az olyan probléma, melynél valóban adatbázis-kezelő alkalmazás használatára lett volna szükség. Az alkalmazás leginkább az informatika órák feladatainak megoldására korlátozódott. Bár kétségtelenül fontos területről van szó, a későbbi tantervekben mindenképpen érdemes mérlegelni azt az életkort, amikor bevezetésre kerül ez a terület. Ugyancsak fontos a jelen vizsgálat tanúsága szerint is, hogy a gyerekek példákat, alkalmazási lehetőségeket lássanak, mintegy indokolva az alkalmazás létjogosultságát. Abban azonban egyetérthetünk, hogy az alsó tagozatos tantervben, de még a felső tagozatos tantervben sincs igazán létjogosultsága ennek az anyagrésznek.

Rendkívül érdekes a népszerű Excel alkalmazás megítélése. Ez az alkalmazás többször visszaköszönt vizsgálatunk során, a legkülönbözőbb helyeken találkozhattunk megemlítésével. A legkedveltebb és a legkevésbé ked- 
velt alkalmazásoknál ugyanúgy megemlítik igen nagy számban a hallgatók, illetve a problémák forrásaként, de sikerélmények színtereként egyaránt megjelölik az Excel alkalmazást. Közvetlen hasznosságát a válaszadók döntő többsége az 1-es és 5-ös pontok közé tette, és viszonylag kevesen gondolták igazán lényegesnek a program használatának megtanulását. (4. ábra) Ez abból a szempontból is érdekes, hogy a szövegszerkesztés mellett ez a terület az, amelyre későbbi iskolai munkájuk során szinte irányultságtól függetlenül minden diáknak szüksége lesz. Így van ez a pedagógusképzésben is.

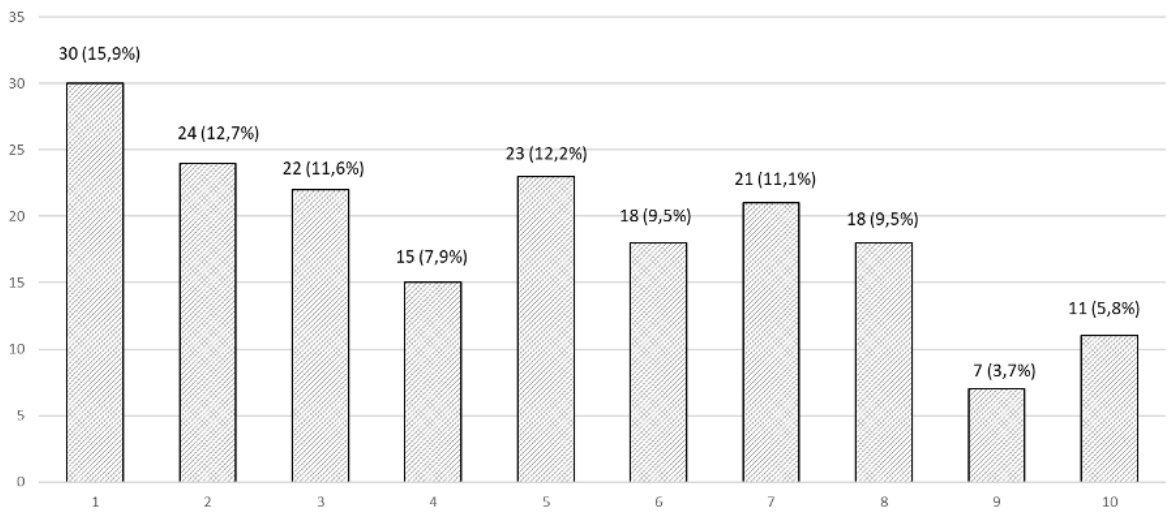

4. ábra

Mennyire tartották fontosnak egy 1-10-es skálán az Excel alkalmazás használatának tanulását pedagógushallgatók az informatika tantárgy keretein belül. $(N=189)$

A szövegszerkesztést a hallgatók döntő többsége igen fontosnak tartotta. A teljes vizsgálatban ez volt az a kérdéskör, ahol a leginkább egyöntetűek voltak a hallgatói válaszok, és a vélekedések döntő többsége a skála 7-es és 10-es pontja között összpontosult. A lehetséges motivációkat végiggondolva valószínűsíthető, hogy itt egyértelműen a hasznosság, mint szempont dominált. Nyilvánvaló, hogy a szövegszerkesztési tevékenység nem igazán szórakoztató az általános és középiskolás diákok számára, azonban már a kezdetektől fogva rendkívül sok példát láthatnak az alkalmazására, melyre szinte minden területen szüksége van egy általános-, illetve középiskolás diáknak. A felsőoktatásban természetesen elengedhetetlen a biztos használata, de igaz ez már a középiskolára is. Tantervfejlesztő tevékenységünk során azonban, nem vitatva a terület fontosságát, figyelembe vettük az életkori sajátosságokat is, ezért az alsó tagozaton szinte kizárólag grafikus dokumentumok létrehozását valósítjuk meg, kizárólag szöveges dokumentumok csak a felsőbb osztályokban készülnek. 
A továbbiakban nyílt végű kérdések segítségével azokat a területeket szerettük volna feltérképezni, melyeket a hallgatók mindenképpen kihagynának az informatikai tantervek anyagából. Nem meglepő módon a témakörök hasznosságáról alkotott vélemények ismeretében várhatóan a programozás, adatbázis-kezelés, az Excel és a hardvereszközök voltak a legkevésbé érdekes vagy hasznosnak vélt területek. Érdekes módon még egy terület jelentkezett, az informatika története, mely nagyon sok tankönyvben csomóponti szerepet játszik. Az értékeket figyelve egyértelmü, hogy a programozás nagyságrendekkel felülmúlja a többi haszontalannak vélt témakör népszerütlenségét. (5. ábra) Ennek okaira már kitértünk.

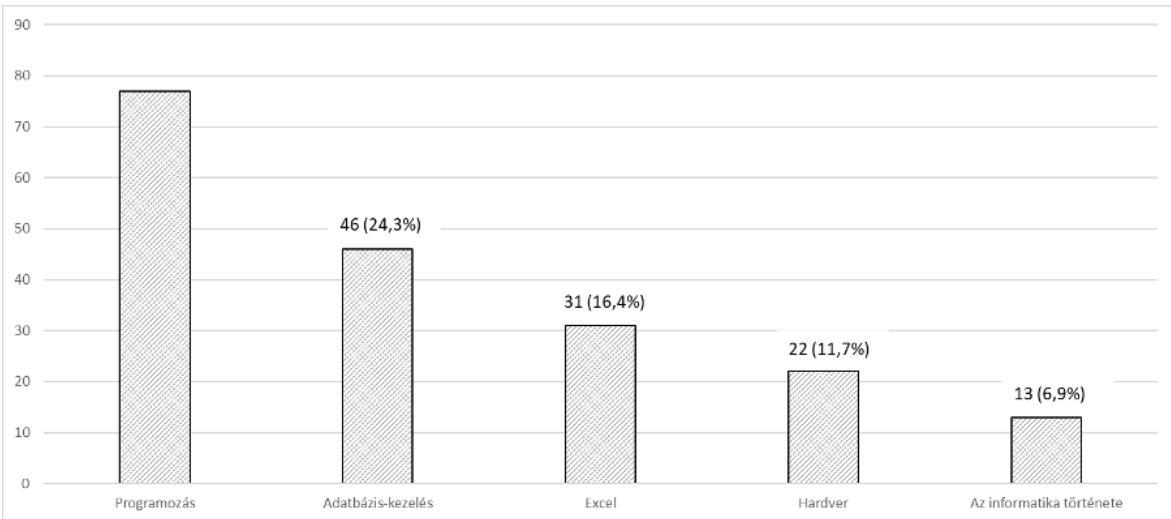

5. ábra

Témakörök, melyeket pedagógushallgatók mindenképpen kihagynának az informatikai tantervek anyagából. A témakörök elöfordulásának relatív gyakorisága. $(N=189)$.

Következő kérdésünk arra vonatkozott, mely témakörök erősítendők a hallgatók véleménye alapján, mit szeretnének inkább tanulni az informatika tantárgy keretében. Nagyon érdekes, hogy a számítógépes grafika vezet. Nem sokkal lemaradva, igen népszerü témakör az eddig önállóan nem megjelenő internetbiztonság, majd a robotika, a kódolás, a programozás, valamint a webszerkesztés témakörei következnek. Érdekes módon, - mint utaltam rá - az Excel itt is elökerült, tehát a hallgatók egy része nem kihagyható, hanem ellenkezőleg, erősítendő témának érzi, minden bizonnyal abból a tapasztalatból kiindulva, hogy milyen sok területen lehet hasznos számukra ez az alkalmazás. Az internetbiztonság önálló témakörként nem jelent meg az eddigi tantervekben, minden bizonnyal a hallgatók tapasztalatai, sokszor kedvezőtlen tapasztalatai mondatják azt velük, hogy a témakört nagyon fontos beépíteni a tantervbe. Ez a tapasztalat egybevágott a tantervszerzők véle- 
ményével és tapasztalataival, éppen ezért ez a témakör mind alsó, mind felső tagozaton, valamint középiskolában igen erőteljes arányban jelenik meg az új Nemzeti alaptanterv digitális kultúra tantárgyában. Érdekes a programozás megítélése, amely az egyik legkedvezőtlenebbül megítélt tartalom, majd igaz, hogy más néven, de az egyik legkifejezettebben erősítendő területként van jelen. Mint arra már utaltunk, nem maga a tevékenység volt problémás a hallgatók számára, hanem a programozási környezet. Például a robotok programozásánál a blokkrendszerủ programozási környezetben szívesen végzik ezeket a feladatokat, hiszen ennek mindig valamilyen eredménye van, valamilyen valós vagy virtuális eszköz müködését tudják befolyásolni és a hétköznapi életben található folyamatokat szimulálnak, modelleznek a programozás során. Az új Nemzeti alaptantervben ez a témakör már alsó tagozatban harmadik osztálytól megjelenik, de természetesen nem elvontan, hanem tevékenységbe, alkotó tevékenységbe ágyazottan, például padlórobotok kódolásának segítségével. (6. ábra)

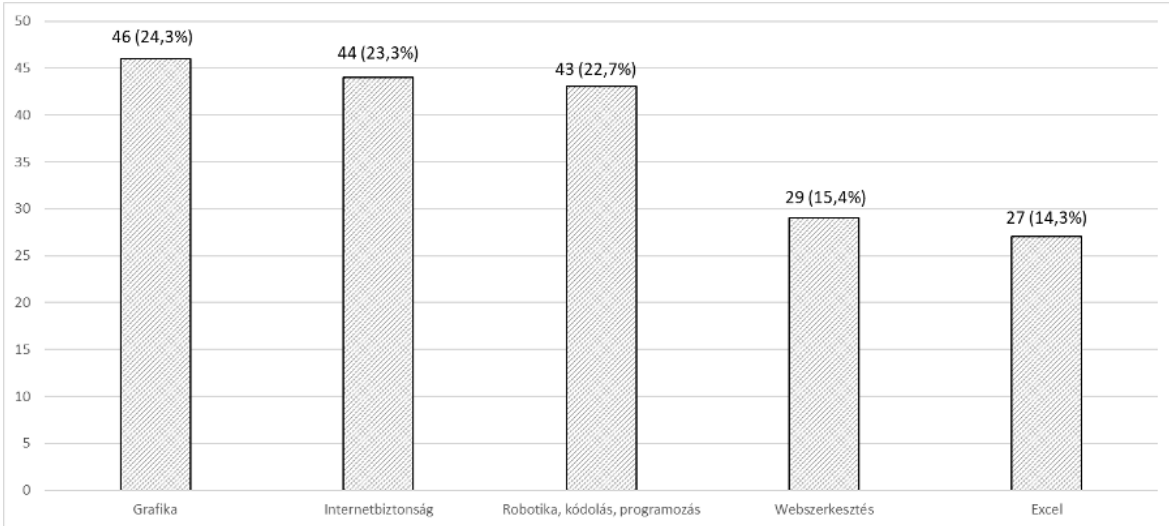

6. ábra

Milyen témaköröket szeretnének inkább tanulni az informatika tantárgy keretében pedagógushallgatók. A témakörök elöfordulásának relatív gyakorisága. (N=189).

A továbbiakban rákérdeztünk nyílt végű kérdések segítségével az informatika órán tapasztalt kudarcélmények forrásaira. Az itt említett esetek, válaszok már sokkal inkább a fekete pedagógia témakörébe tartoznak, mint az előbb említett módszertani problémák. Az alkalmazások közül a legtöbb kudarcot, igen erőteljesen elkülönülve a többi alkalmazástól, az Excel okozta. Természetes, hogy nem megfelelő módszertannal tanítva, jelentőségét nem bemutatva, illetve túl korán kezdve a tanítását, a hallgatók számára kudarc forrásaként jelentkezhet ez az alkalmazás. Megdöbbenve tapasztaltuk, hogy a hallgatók mintegy 4\%-a általános iskola alsó tagozatában ismerkedett meg 
az Excel használatával, holott ezt semmilyen tantervi háttér nem indokolta. Nagyon gyakran előfordul, hogy a tanár ismeri az alkalmazást - aki általában nem tanítói végzettségü, hanem felső tagozatban is tanító informatika tanár -, ezért ezt az ismeretanyagot alsó tagozatban is oktatja. Ezenkívül a programozás és az adatbázis-kezelés szerepelt még a kudarcélmények forrásaként. Nem meglepő módon, közvetlen kapcsolatban a területek előzőekben megítélt fontosságával, az informatikaórán megélt sikerélmények leginkább a szövegszerkesztés és a prezentációkészítés köré összpontosulnak. A szövegszerkesztés némileg meglepő lehet abból a szempontból, hogy nem igazán szórakoztató tevékenység. A sikerélmények valószínűleg nem is magából a szövegszerkesztés folyamatából, hanem annak eredményéből táplálkoztak, hiszen minden bizonnyal nagyon sok területen tudták alkalmazni a gyerekek az itt megszerzett tudást. A sikerélmények forrásaként is szerepel az Excel, mert éppen ahogy a sikertelenség forrásaként is megjelent, nyilvánvaló, hogy helyes módszertannal, megfelelő életkorban tanítva és használatának létjogosultságát a gyerekek életéből vett példákkal alátámasztva, felső tagozatban helye van ennek az alkalmazásnak. A prezentációkészítés nemcsak hasznos, hanem a grafikai elemek, animációk beemelése miatt jóval szórakoztatóbb és motiválóbb tevékenység is a szövegszerkesztésnél.

\section{Az informatikatanulás során átélt nehézségek, kudarcok}

A továbbiakban az informatikaórán elszenvedett kudarcok okaira és körülményeire kérdeztünk rá nyílt végü kérdések segítségével. Egyezést tapasztalva a fekete pedagógia kutatásaival (Hunyadyné et al., 2006) láthatóvá vált, hogy a kudarcélmények döntő többsége sajnálatos módon a pedagógus személyével, cselekedeteivel kapcsolatos. Rengeteg olyan kudarcélményről számoltak be a hallgatók, mely a pedagógus türelmetlenségével, viselkedésével, nemtörődömségével, helytelen értékelési gyakorlatával függött össze, az ezzel kapcsolatos negatív élmények adják az összes negatív élmény 74 \%-át. Sok esetben a pedagógus tárgyi tudásának a hiánya is megjelenik, mely az informatika tantárgy történetét ismerve nem csodálható. Főleg a tárgy bevezetésének időszakában nagyon sok szakképzetlen, sőt pedagógus diplomával nem rendelkező, például mérnök végzettségű kolléga tanította a tárgyat.

„A tanár nem segített nekünk mikor elakadtunk valamiben, de ha a társunkat megkértük, hogy segítsen leszidott minket. Egyértelmünek gondolta, hogy amit ő tud, azt mi is."

„Nem tudtam megtanulni teljesen a számítógép részeit és az informatikához köthető neveket és évszámokat, és mindig ebből írtunk dolgozatot, viszont emiatt nem sikerült jól." 
„A félév végén 4/5-re, ezért külön kellett felelnem az osztály előtt az informatika kialakulásának történetéből, a fontosabb személyekből. Nem tudtam pontosan az évszámokat ezért félév végén négyest kaptam."

„Az órák abból álltak, hogy mindenkinek hangosan fel kellett olvasnia egy anyagrészt..."1

A sikertelenségek, kudarcélmények másik forrása az egyéni haladási ütem figyelmen kívül hagyásából következik. A hallgatók mintegy 15 \%-a számolt be olyan, mai napig ható kudarcokról, melyeket a lemaradás, a tananyag követésében történő problémák okoztak, illetve az, hogy ez a lemaradással együtt járó hátrány a számonkérésben és az értékelésben is megjelent. A nem kellő tempójú, vagy nem kellő módon megalapozott informatikatanítás sok hallgatóban kilátástalanságérzést, pánikot okozott és hozzájárult a tárggyal kapcsolatos ellenérzések kialakulásához.

„Lassabban gépeltem, mint az osztálytársaim, így előfordult, hogy lemaradtam és a tanár nem mondta/mutatta meg újra a feladatot, utána én voltam végig cikizve az órán."

„Túl gyorsan haladt a tanárnő, nem tudtuk követni, hogy mikor hova kattint.”

"Gyorsan haladtunk, ezáltal nem tudtuk sokszor követni a tanárt, ezért sok mindent nem tanultunk meg rendesen."

„Mindenről lemaradok, nem sikerül semmi, elveszik az anyagom az éterben."

Viszonylag nagy számban jelentkeznek azok a kudarcélmények, melyek a nem megfelelő szoftver vagy hardver háttérből adódtak, például a nem üzembiztosan vagy túlságosan lassan müködő számítógépek lehetetlenné tették a haladást, illetve nagyon sokan számolnak be olyan kudarcélményekről, melyek a hosszabb időn keresztül, nagy fáradsággal alkotott munkák elvesztéséből adódnak. Kis részben, de kifejezetten megjelenik egy olyan kudarc csoport, mely abból adódik, hogy tulajdonképpen nem is tanították az informatika tantárgyat, az informatikaórák helyett szabadfoglalkozás, udvari játék vagy más tantárgyak órái voltak.

„Számomra az volt a legrosszabb, hogy középiskolában nem tartottak informatika órát, helyette facebookozás volt."

„Mindig más tanár jött be infóra és a saját tárgyából tartott órát. Informatikánk gyakorlatilag évekig nem is volt."

${ }^{1}$ Értsd: középiskolában. 
„Hol ezért, hol azért, de majdnem mindig elmaradtak az óráink. Szerencsére úgy csinálták meg az órarendet, hogy utolsó óra volt, ezért mindig előbb elmehettünk."

Többen számoltak be arról is, hogy érthetetlen módon, de ennek ellenére is számonkérték valamilyen formában az informatika tananyag egy részét.

„Év végén megadtak egy listát, hogy miből írunk témazárót. Volt nagy rohangálás, mert infóóra szinte nem volt, 4 tanárunk volt egy év alatt, mindenki ott szedte össze a tudását, ahol tudta. Nekem szerencsém volt, apám elmagyarázott mindent, gépünk is volt otthon."

\section{Összegzés}

A vizsgálat számos egyéb tanulsággal is szolgált számunkra. Bízunk benne, hogy kutatásunk, ha csak kis adalékokkal is, de hozzájárult az informatika-digitális kultúra tantárgy megújításához, a jövő tanulói és pedagógussikereinek megalapozásához, a digitális kompetenciák, az informatikai eszközökkel megvalósított hatékony problémamegoldás fejlesztéséhez.

A kutatás során tapasztalhattuk, hogy egy újabb területen is érvényesült a fekete pedagógia hatásrendszere, valamint azt , hogy a tanulók tapasztalatai, még ha objektivitásuk megkérdőjelezhető is, fontos információkkal szolgálhatnak a pedagógia számára. Közvetlen hasznosulásként az informatika-digitális kultúra tantárgy módszertanának átalakítását/kidolgozását, valamint a tantervfejlesztésben betöltött szerepüket említhetjük.

\section{Irodalom}

A 2020-as NAT-hoz illeszkedő tartalmi szabályozók: Kerettanterv az általános iskola 1-4. évfolyama számára (2020). Oktatási Hivatal. https://bit.ly/2Ydiu5T (2020.04.20.)

Az Iskolai Digitális Oktatás Megújítási Terve (2016). IVSZ. https://bit.ly/3aYTiCX (2020.04.20.)

Nemzeti alaptanterv (2020). Magyar Közlöny 2020/17. https://bit.ly/2W13eX6 (2020.04.20.)

Falus, I., Golnhofer, E., Kotschy, B., M. Nádasi, M. \& Szokolszky, Á. (1989). A pedagógia és a pedagógusok. Akadémiai Könyvkiadó.

Holt, J. (1991). Iskolai kudarcok. Gondolat Kiadó.

Lénárd, A. (2016). Paperttől a konnektivizmusig: tanulás-tudás az információs társadalomban. In Zsakó, L. \& Szlávi, P. (Eds.), INFODIDACT 2016 Konferenciakötet (pp. 2-9). Webdidaktika Alapítvány.

Lénárd, A. (2019). A digitális környezet következményei és lehetőségei kisgyermekkorban. Iskolakultúra, 29(4-5), 99-114. https://doi.org/10.14232/ISKKULT.2019.4-5.99 
Hunyadyné, M. Nádasi, M., \& Serfőző, M. (2006). Fekete pedagógia. Argumentum Kiadó.

Pajares, M. F. (1992). Teacher's Beliefs and Educational Research: Cleaning Up a Messy Constucts, Rewiew. of Educational Research, 62(3), 307-332. https://doi. org/10.3102/00346543062003307

Rutschky, K. (1988). Schwarze Pädagogik. Quellen zur Naturgeschichte der bürgerlichen Erziehung. Ullstein Sachbuch.

Szekszárdi, J. (2007). A fekete pedagógia jelenségvilága: diszfunkcionális pedagógiai hatások az iskolában. Új Pedagógiai Szemle, 57(5), 117-121.

Szlávi, P. \& Zsakó, L. (2003). Az informatikaoktatás téveszméi. Inspiráció, 11(1), 14-20. https://doi.org/10.5485/TMCS.2003.0023

Wubbels, T. (1992). Talking account of students teachers' preconceptions. Teaching and Teacher Education, 8(2), 137-149. https://doi.org/10.1016/0742051X(92)90004-M 


\title{
Lénárd, A.
}

\begin{abstract}
Black pedagogy - experiences of informatics education
Based on the phenomenon of black pedagogy and the results of pedagogical research, the author examines the experiences of teaching university students, especially their negative experiences, during their own informatics education in primary school. He examines the experiences and beliefs that affect the content, the topic and perceived usefulness of informatics subject. Which areas would be strengthened or left, and what personal, negative experiences do they have in relation to the subject. The experience of non-representative research can be well utilized in the renewal of the subject of informatics, and in the development of curriculum content design of the newly created digital culture subject. Namely the experiences drawn from the study were fully in line with the aspirations of the curriculum developers to create a subject in line with the expectations of the information society and the interests and needs of the students. The experience can be used very effectively in teachers' education as well, on one hand in the elimination of the influence of black pedagogy, and on the other hand in the development of modern methodological solutions.
\end{abstract}

Keywords: informatics, black pedagogy, experience, curriculum development, remembrance

Lénárd András: https://orcid.org/0000-0003-3467-9456 